\title{
Study on antibacterial activity of various water storing vessels
}

\author{
Kailash Wagh ${ }^{1, *}$, Nagendra A. ${ }^{2}$, Amit Vairagade ${ }^{3}$ \\ ${ }^{1}$ Associate Professor, ${ }^{2}$ Professor \& HOD, ${ }^{3}$ MBBS Student, Dept. of Microbiology, Dr. Ulhas Patil Medical College, Jalgaon, \\ Maharashtra, India
}

*Corresponding Author:

Email: kwkailashwagh8@gmail.com

\begin{abstract}
Water used for human consumption must be safe and free from microbes. Storing water in copper has been used since long time in India, also evident in ancient texts of Ayurveda. Present study aims to evaluate the efficacy of various water storing vessels in purifying drinking water especially in terms of antibacterial (anti-Escherichia coli) activity. The water was collected from Waghur River, Jalgaon and stored in different vessels for 5 days like copper, stainless steel and plastic.Bacterial growth was observed before and after storage. We found the significant reduction in the number of coliform bacteria in water stored in copper vessels than stainless steel and plastic vessels. We observed the benefit of using a copper-based device, which is effective and cheap for storage of water and can be used to made bacteria free water.
\end{abstract}

Keywords: Anti-Escherichia coli activity, Bacterial growth, Coliform bacteria.

\section{Introduction}

The Important of water for all living things can be understood by the old saying "Water has no enemy". The river water is most likely have coliforms as contamination. The contaminated water when consumed causes infections, hence responsible for increase rate of morbidity and mortality. So it is often suggested that the river water when collected should be stored for 5-10 days which reduces the bacterial level by $90 \%{ }^{2}$ The other ways to purify the collected water by filtration, boiling, long storage, irradiation, the use of metal like copper, silver as well as the use of oxidants such as the halogens, ozone, hydrogen peroxide and potassium permanganate. Traditional methods of water purification are cloth filtration, sedimentation and boiling. Coagulants of plants \& soil origins have been used for water purification in developing countries are in form of such fluvial clays earth from termite hills, potash alum (trona). ${ }^{3}$ The most serious water pollutants are pathogenic organisms. In many parts of the developing world, drinking water is collected from unsafe surface sources outside the home and is then held in household storage vessels this increases chances of water contamination more during storage or at the source due to improper handling and transport. Hence it is important for safety point of view to maintain the quality of drinking water during storage. Proper storage is an inexpensive and safe strategy but become effective if it is store in appropriate vessels. Studies have shown that point-of-use household interventions contribute to $30-40 \%$ reduction in diarrhoeal diseases. Moreover, in countries such as India where only $28 \%$ of households have piped water, point-of-use interventions are a sustainable way to provide safe drinking-water. ${ }^{4}$ The Indian ayurveda describes storing water in a copper vessel overnight and drinking it in the mornings for many health benefits. Copper is known for its antimicrobial, anti- inflammatory, antioxidant and anticarcinogenic activities. Yogis and traditional households in India have been utilizing a simple, practical and effective method of drinking water in its most holistic way for thousands of years and also till today. Most of the studies proved antibacterial activity of various storage vessels among them copper vessels showed more effectiveness. Preethi Sudha VB et.al study described the application of copper for sterilize drinking water. ${ }^{4}$ Bacteria, yeasts, and viruses are rapidly killed on metallic copper surfaces, and the term "contact killing" has been coined for this process. ${ }^{5}$

Present study aims to evaluate the efficacy of various vessels in purifying drinking water especially in terms of antibacterial (anti-Escherichia coli) activity.To actually test the water for specific harmful viruses, protozoa and bacteria is time consuming \& expensive. Therefore water quality control personnel usually analyze water for the presence of coliform bacteria (e.g. Escherichia coli), Coliforms are used as water quality indicators for two main reasons: i) unlike other coliforms, E.coli is a parasite living only in the human or animal intestine. Voided in feces it remains viable in the environment only for a few days. Detection of E.coli in drinking water therefore is taken as evidence of recent pollution by human or animal feces. ii) Coliforms may be associated with the sources of pathogens contaminating water and their presence in drinking water may indicate. ii) The analysis of drinking water for coliforms is relatively simple, economical and efficient. ${ }^{6}$ Acceptable water quality from the concern source achieved when there are especially no bacteria of fecal origin that is coliforms.

\section{Materials and Methods}

Water sample from Waghur River, Jalgaon was collected under sterile condition in presterilized conical flask. Different vessels like plastic bottle, stainless steel 
\& copper was taken (Fig. 2, 3, 4). Water sample was tested for the presence of coliform before store it in the different vessels. Before storage a loopful sample of water was inoculated on 3 MacConkey's agar and then colonies observed and identified with standard procedure (Fig. 6). $250 \mathrm{ml}$ of collected water sample was transferred under aseptic conditions into these 3 vessels. These 3 Labelled vessels then were kept at room temperature with fitted lids for 5 days. Estimation of microorganisms in water (stored) in different vessels done by Miles \& Mishra method and mean plate count. ${ }^{7}$ In order to estimate the microbial load per millilitre of water, 8 fold serial dilutions of stored water were made (Fig. 5). For dilution we used normal saline, because it is best for immediate inoculation. The plates of MacConkey's medium were made dried for at least, 1 hour at $37^{0} \mathrm{C}$ before inoculation. Sterile calibrated dropping pipette was used to measure accurately 0.02 $\mathrm{ml}$ bacterial suspension of each dilution and dropped it on the plate medium from height of $2.5 \mathrm{~cm}$. Each of six plates receives one drop of each dilution in separate numbered sectors. Inoculated plates then were kept in incubators in inverted position. Counts are made in the drop areas showing the largest number of colonies without confluence; the total of the six counts gives viable counts/ $0.1 \mathrm{ml}$ of the dilution. Bacterial count $(\mathrm{CFU}) / \mathrm{ml}$ for copper vessel, plastic bottle vessel and stainless steel vessel showed in Table 1. Bacterial counts also were calculated by taking mean of six plates. $^{7}$ (Table 2, 3 and 4 mean plate count)

\section{Observations and Results}

Before storage, inoculation of water done on MacConkey's agar showed numerous colonies > $10 .{ }^{5}$ The estimation of number of bacterium from different water stored vessels was done by Miles \& Mishra method. It was observed that no occurrence of bacterial isolates in copper vessel as compared to other vessels. The result of bacterial count after storage in different vessels showed in Table 1.

Table 1: Estimation of bacterial count by Miles and Mishra method

\begin{tabular}{|l|c|c|}
\hline \multicolumn{2}{|c|}{ Type of storage vessels } & CFU (Colony forming unit) \\
\hline \multicolumn{2}{|c|}{ Before storage } & $>10^{5}$ \\
\hline $\begin{array}{l}\text { After } \\
\text { Storage }\end{array}$ & Plastic & $+++(7000 \mathrm{CFU} / \mathrm{ml})$ \\
\cline { 2 - 3 } & Stainless steel & $++(6000 \mathrm{CFU} / \mathrm{ml})$ \\
\cline { 2 - 3 } & Copper & $\begin{array}{c}\text { No growth } \mathrm{detected} \\
(0 \mathrm{CFU} / \mathrm{ml})\end{array}$ \\
\hline
\end{tabular}

Table 2, 3, 4 represents the mean aerobic bacterial plate count of water in different storage vessel. After 5 days of storing water in storage vessel, we found that the bacterial count was negligible in copper vessel and maximum in plastic and stainless steel vessel.

Table 2: Mean of colonies count of water stored in plastic vessel

\begin{tabular}{|c|c|c|c|c|c|c|c|}
\hline Stage & \multicolumn{6}{|c|}{ Plastic } & P Mean \\
\hline $10^{\wedge}-1$ & 7 & 8 & 6 & 6 & 4 & 4 & 5.83 \\
\hline $10^{\wedge}-2$ & 7 & 7 & 6 & 6 & 5 & 4 & 5.83 \\
\hline $10^{\wedge}-3$ & 6 & 5 & 6 & 5 & 4 & 4 & 5.00 \\
\hline $10^{\wedge}-4$ & 5 & 5 & 5 & 5 & 4 & 4 & 4.67 \\
\hline $10^{\wedge}-5$ & 5 & 4 & 4 & 4 & 4 & 3 & 4.00 \\
\hline $10^{\wedge}-6$ & 4 & 4 & 3 & 4 & 4 & 3 & 3.67 \\
\hline $10^{\wedge}-7$ & 5 & 4 & 4 & 4 & 4 & 3 & 4.00 \\
\hline $10^{\wedge}-8$ & 4 & 4 & 3 & 3 & 3 & 4 & 3.50 \\
\hline & & & & & & Mean & 4.56 \\
\hline
\end{tabular}

Table 3: Mean of colonies count of water stored in stainless steel vessel

\begin{tabular}{|c|c|c|c|c|c|c|c|}
\hline Stage & \multicolumn{6}{|c|}{ Steel } & S Mean \\
\hline $10^{\wedge}-1$ & 8 & 8 & 7 & 7 & 6 & 7 & 7.17 \\
\hline $10^{\wedge}-2$ & 7 & 8 & 7 & 6 & 7 & 5 & 6.67 \\
\hline $10^{\wedge}-3$ & 6 & 6 & 7 & 7 & 5 & 4 & 5.83 \\
\hline $10^{\wedge}-4$ & 5 & 5 & 5 & 4 & 4 & 5 & 4.67 \\
\hline $10^{\wedge}-5$ & 5 & 4 & 4 & 4 & 4 & 3 & 4.00 \\
\hline $10^{\wedge}-6$ & 5 & 4 & 3 & 4 & 4 & 3 & 3.83 \\
\hline $10^{\wedge}-7$ & 5 & 4 & 3 & 3 & 4 & 4 & 3.83 \\
\hline $10^{\wedge}-8$ & 4 & 3 & 3 & 3 & 4 & 4 & 3.50 \\
\hline & & & & & & Mean & 4.94 \\
\hline
\end{tabular}


Table 4: Mean of colonies count 0 of water stored in copper vessel

\begin{tabular}{|c|c|c|c|c|c|c|c|}
\hline Stage & \multicolumn{6}{|c|}{ Copper } & C Mean \\
\hline $10^{\wedge}-1$ & 2 & 2 & 2 & 1 & 1 & 2 & 1.67 \\
\hline $10^{\wedge}-2$ & 1 & 1 & 1 & 2 & 1 & 1 & 1.17 \\
\hline $10^{\wedge}-3$ & 1 & 0 & 1 & 1 & 1 & 1 & 0.83 \\
\hline $10^{\wedge}-4$ & 0 & 0 & 0 & 0 & 0 & 0 & 0.00 \\
\hline $10^{\wedge}-5$ & 0 & 0 & 0 & 0 & 0 & 0 & 0.00 \\
\hline $10^{\wedge}-6$ & 0 & 0 & 0 & 0 & 0 & 0 & 0.00 \\
\hline $10^{\wedge}-7$ & 0 & 0 & 0 & 0 & 0 & 0 & 0.00 \\
\hline $10^{\wedge}-8$ & 0 & 0 & 0 & 0 & 0 & 0 & 0.00 \\
\hline & & & & & & Mean & 0.46 \\
\hline
\end{tabular}

The average number of bacterial colony in plastic vessels was 4.56 and in stainless steel vessels was 4.94 . The unpaired test statistical value was 0.62 with p value 0.54 at $5 \%$ level of significance, $\mathrm{p}$ value more than 0.05 shows no significant difference in average number of bacteria grown. (Table 5)

Table 5: Comparison of average number of bacterial colony in plastic and stainless steel vessel

\begin{tabular}{|l|c|c|c|c|}
\hline Group & Mean & S.D. & t value & p value \\
\hline Plastic & 4.56 & 0.92 & \multirow{2}{*}{0.62} & \multirow{2}{*}{0.540} \\
\hline Steel & 4.94 & 1.43 & & \\
\hline
\end{tabular}

The average number of bacterial colony instainless steel vessels was 4.94 and in copper vessels was 0.45 .The unpaired test statistical value was 8.03 with p value 0.00 at $5 \%$ level of significance p value less than 0.05 shows significant difference in average number of bacteria grown. (Table 6)

Table 6: Comparison of average number of bacterial colony in stainless steel vessel and copper vessels

\begin{tabular}{|l|c|c|c|c|}
\hline Group & Mean & S.D. & t value & p value \\
\hline Steel & 4.94 & 1.43 & \multirow{2}{*}{8.03} & 0.000 \\
\hline Copper & 0.45 & 0.67 & & \\
\hline
\end{tabular}

The average number of bacterial colony in plastic vessels was 4.56 and in copper vessels was 0.45 .

The unpaired test statistical value was 10.16 with p value 0.00 at $5 \%$ level of significance $p$ value less than 0.05 shows significant difference in average number of bacteria grown (Table 7)

Table 7: Comparison of average number of bacterial colony in plastic and copper vessels

\begin{tabular}{|l|c|c|c|c|}
\hline Group & Mean & S.D. & t value & p value \\
\hline Plastic & 4.56 & 0.92 & \multirow{2}{*}{10.16} & \multirow{2}{*}{0.000} \\
\hline Copper & 0.45 & 0.67 & & \\
\hline
\end{tabular}

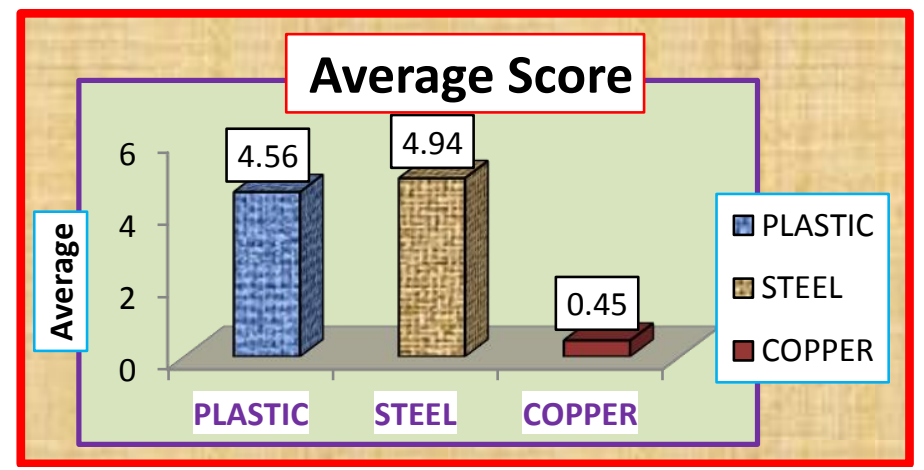

Fig. 1: showing less number of bacterial counts in water stored in copper vessel 


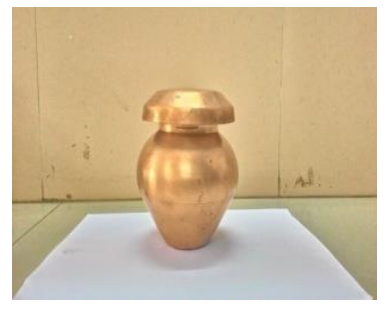

Fig. 2: Copper

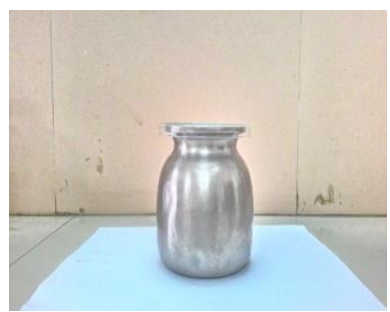

Fig. 3: Stainless

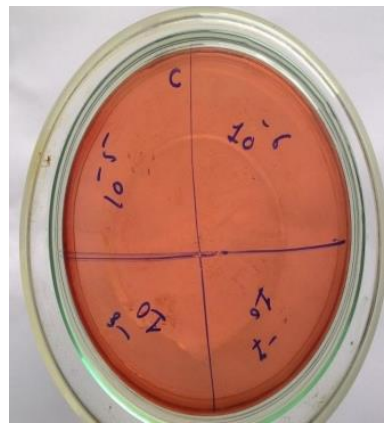

Copper

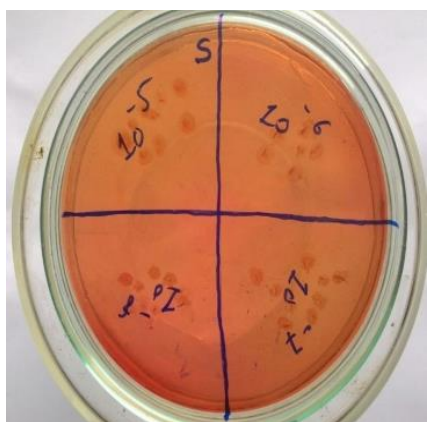

Stainless Steel

\section{Fig. 4: Dilution}
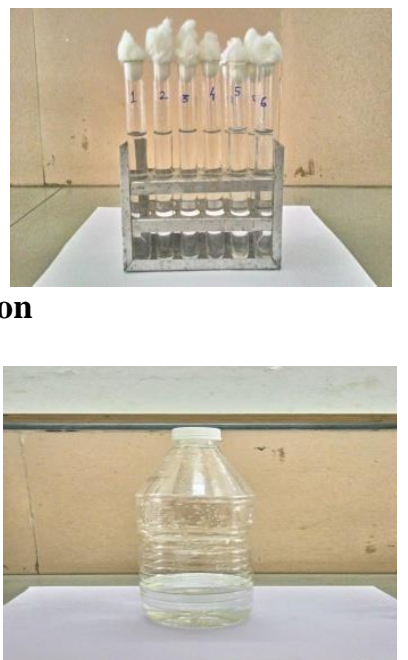

Fig. 5: Plastic

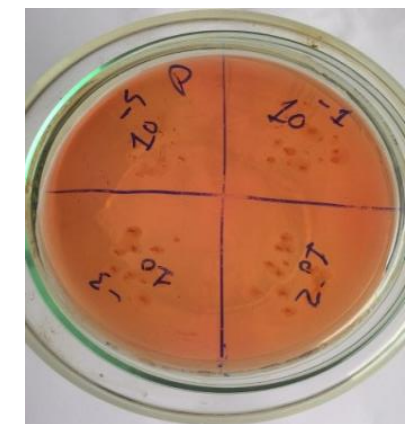

Plastic

Fig. 6: Showing bacterial growth (CFU) on MacConkey's agar

\section{Discussion}

Drinking water may become contaminated during handling, transport, and at the source or during storage. Drinking water must be free from chemical substance and microorganisms, which might be dangerous to the health user. Therefore strategies to reduce water borne discuses transmission must be adopted, there are many methods for the purification, and storage also is one of them. Our study studied antibacterial activity of various water storing vessels for that we showed microbial analysis of stored water in different storage vessels; namely plastic, copper and stainless steel. It was observed that by 5 days of storage of water in copper vessel could eliminate almost all aerobic bacteria as compare to the other two vessels. The decreasing succession of bacterial isolateswere in order copper vessel > plastic bottles> stainless steel (Fig. 1).We estimate these bacterial counts by Miles \& Mishra and mean colony counts method. The method of Miles \& Mishra has been the standard surface inoculation method for estimating the number of viable bacteria since many years in fluid. ${ }^{8}$ It also has the advantage of being faster and producing less bacterial contamination of the working surface. Our study result showed that the number of coliforms reduced more in water stored in copper vessels this finding similar with other studies described here. Idika $\mathrm{N}$ et.al ${ }^{1}$ showed effects of long storage of water in sterile clay pots and plastic containers by estimation of viable count after $2,5,10$, 15 , and 21 days of storage, here method of estimation was Miles \& Mishra method. Mehta et al. ${ }^{9}$ demonstrated that the MPN of coliform organism present in sewage contaminated water stored in copper vessel was negligible within 36 hours of storage. Radha R. and Susheela P. demonstrated that most probable number of coliform organisms present in lake water stored in four different vessels showing decreasing succession of bacterial isolated it was copper vessels $>$ clay vessels > stainless steel vessels > plastic bottles. ${ }^{10}$ Olanrenja Onigbogi and OluwatoyinOgunyemi ${ }^{11}$ study showed collection of water sample form the source of water supply (springs), household regular storage container and noted statistically significant association while comparing the mean total coliform count of water sample from springs regular storage container, covered kegs \& covered kegs with taps. Sudha et al. ${ }^{4}$ reported that water stored overnight in copper pot gave less counts of E.coil, Salmonella typhi \& Vibrio cholerae demonstrating inactivation of these bacteria. Sarsan Sreedevi ${ }^{6}$ study confirmed that waterborne pathogen such as Salmonella typhimurium and Vibrio cholerae are inactivated by storage of water in copper vessels 
within 24 hrs. Ravichandran et.al ${ }^{12}$ showed microbial analysis of water stored in 10 different container and find out the decrease in coliform bacterial population by $3 \mathrm{hrs}$ of storage itself and complete removal of coliform bacteria leading to microbial free safe water with in 24 hrs in water stored in brass, copper \& silver container. It can be inferred that copper metal is the most effective metal in killing the coliforms. Espírito SC et al. described action of copper during storage, copper ion level of cells remained high throughout the killing phase, suggesting that cells become overwhelmed by their intracellular copper and he also concluded that the copper ion responsible for complete killing of bacteria by destruction of its outer protective cell wall. ${ }^{13}$ However, the mechanisms of action of copper in bacteria are not completely understood. ${ }^{4}$

\section{Conclusion}

The study showed the effect of different type of storage containers on coliform count in drinking water of rural areas. As copper vessel is more effective than plastic and stainless steel vessels in killing the bacteria during water storage.Therefore result of our study stated that storing water in copper vessels in being simple, practicable cheap and better, so it is therefore recommended for use.

\section{References}

1. Idika N. Odugbemi T., Ogunsola FT. An assessment of existing common traditional methods of water purification. Afr. J .ClinExpMicrobiol. 2002;3(1):41-4.

2. Taylor EW. The examination of water and water supplies.J.A. Churchill Ltd.104 Gloucester place,W.I.(Thresh,Beale and Suckling): $7^{\text {th }}$ ed;1958.
3. Khin New, O.O. Khin-Sann-Aung and Myat-Thida. Effectiveness of potash alum decontaminating household water. Diarrhea. Dis. Res. 1993.11(3):171-4.

4. Preethi Sudha VB, Ganesan S, Pazhani

GP, Ramamurthy T, Nair GB, and Venkatasubramanian $\mathrm{P}$. Storing drinking-water in copper pots kills contaminating diarrheagenic bacteria. J. Health. Popul. Nutr. 2012; 30(1): 17-21.

5. Gregor G, Rensing C, Solioz M. Metallic copper as an antimicrobial surface. Appl. Environ. Microbiol. 2011;77(5):1541-51.

6. Sreedevi S. Effect of storage of water in different metal vessels on coliforms. Int. J. Curr. Microbiol. App. Sci. 2013;2(11):24-9.

7. Brown R and Poxton IR.Centrifuges, colorimeters and bacterial count Mackie \& McCartney, Practical medical microbiology, $14^{\text {thed: }}$ 48:850-1.

8. Marry PE. Slack and Wheldon DB. A simple and safe volumetric alternative to the method of Miles, Mishra and Irwin for counting viable bacteria. Med. Microbiol 1978;11(3):541-5.

9. Mehta, M., A.Dass and K.J.Singh. Keeping quality of drinking water. Human Ecology 2004;16:125-8.

10. Radha R. and Susheela.P .Comparative microbiological analysis of water stored in different storage vessels. Int $\mathbf{J}$ Pharm Bio Sci 2015;6(2):121-8.

11. OlanrewajuOnigbogi and OluwatoyinOgunyemi. Effect of Storage Containers on Quality of Household Drinking Water in Urban Communities in Ibadan, Nigeria.International Journal of Public Health Science. 2014;(3)4:253-8.

12. Ravichandran P., Subha K., Sugumaran P., and Unnamalai N. Effect of storage Containers on Coliforms in Household Drinking Water. Int. J. Curr. Microbiol. App. Sci. 2016;5(1):461-77.

13. Espírito Santo C, Lam EW, Elowsky CG, Quaranta D, Domaille DW, Chang CJ, et.al.Bacterial killing by dry metallic copper surfaces. Appl. Environ. Microbiol. 2011;77:794-802. 